УДК 541.2

\title{
ПРИКОСНОВЕНИЯ НА АТОМНОМ УРОВНЕ
}

Сирашева Любовь Михайловна МАОУ «Центр образования № 35», г. Уфа Субханкулова Эмилия Ильдаровна ФГБОУ ВО «Башкирский государственный университет»

Аннотация: в статье рассматривается тема вирусного заражения, почему молекулярный уровень является одним из важнейших и механизм прикосновения на атомном уровне, за счет чего он происходит и каким образом. Доказывается, при помощи химии, существование электромагнитных полей, из-за которых человек не может дотронуться до предметов.

Ключевые слова: поля, атом, электроны, прикосновение, вирус.

\section{TOUCH ON THE ATOMIC LEVEL}

\section{Sirasheva Lybov Mikhailovna Subkhankulova Emilia Ildarovna}

\begin{abstract}
: the article discusses the topic of virus infection, why the molecular level is one of the most important and the mechanism of touch at the atomic level, how does it happen. It is proved, with the help of chemistry, the existence of electromagnetic fields, because of which a person cannot touch objects.
\end{abstract}

Key words: fields, atom, electron, touch, virus.

\section{Введение}

Bce, что нас окружает, состоит из атомов. Каждый день люди взаимодействуют с большим количеством предметов. Прикасаясь к какомулибо объекту, мы ощущаем его воздействие на себе.

Предмет может быть гладким или шершавым, теплым или холодным, мягким или твердым. Когда вы дотрагиваетесь пальцем до другого человека, кажется, что вы соприкасаетесь. И это чувство есть у нас с рождения, никто даже не задумывается о том, как это происходит на атомном уровне.

Получается, мы можем сказать, что прикосновение - это когда одна частица одного предмета физически или механически соприкасается с хотя бы одной частицей другого предмета. 


\section{ВСЕРОССИЙСКИЙ ИССЛЕДОВАТЕЛЬСКИЙ ФОРУМ

Все достаточно просто и понятно. Но что происходит на атомном уровне?

\section{Цель работы:}

Доказать, при помощи химии, существование электромагнитных полей, из-за которых человек не может дотронуться до предметов. То, что человек чувствует их, но не касается.

В школе, на уроке физики, рассказывают о том, что вокруг любого тела существуют различные физические поля, определяемые процессами, происходящими внутри него.

Человек не является исключением, вокруг него также существует большое количество разных энергетических полей:

1. Электромагнитные поля

2. Биомагнитные поля

3. Магнитные поля внутренних органов, кожи, мышц, глаз

4. Радиоволны сверхвысоких частот

5. Нейромагнитные поля

6. Низкочастотные электрические и магнитные поля

7. Акустические поля и др [2 ] .

На самом деле, мы не можем прикоснуться к другому человеку или предмету. Рассмотрим это с точки зрения химии.

Во вселенной происходит достаточно много разных химических реакций. Взаимодействие между разными веществами обуславливается тем, что химические элементы делятся электронами.

Всё вокруг состоит из молекул, которые в свою очередь состоят из атомов. Атом - это ядро, окруженное оболочкой электронов на его орбите. Электрон - это отрицательно заряженная частица [1, с 24].

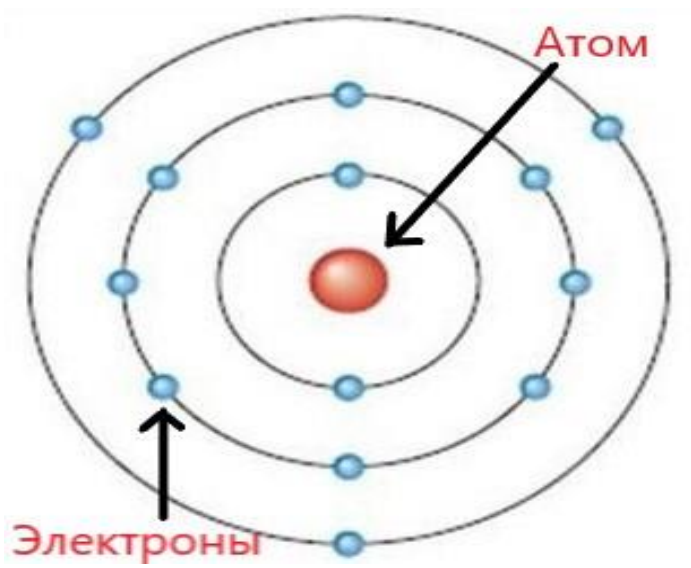

Рис. 1. Строение атома алюминия 


\section{ВСЕРОССИЙСКИЙ ИССЛЕДОВАТЕЛЬСКИЙ ФОРУМ СТУДЕНТОВ И УЧАЩИХСЯ}

Следовательно, наше тело и книга, к которой мы прикасаемся, состоят из большого количества атомов, а когда два атома приближаются друг к другу, они не образуют химическую реакцию, потому что электроны отталкивают друг друга, так как они имеют одинаковый отрицательный заряд. За счет этого электромагнитного отталкивания между нашим пальцем и книгой образуется пространство.

Сила, с которой отталкиваются электроны, очень велика, поэтому мы никогда не сможем прикоснуться по-настоящему к чему-либо.

Хорошо наточенный нож спокойно может разрезать фрукт, овощ или мясо. Но он так и не дотронется до какой-либо материи, он просто вытеснит ее с пути, при помощи силы отталкивания электронов.

Мы можем держать вещи, потому что на микро-уровне нет идеально плоской поверхности, и существует трение.

Вещи прилипают друг к другу через химические связи, фиксируясь на несовершенствах поверхности, когезии /адгезии и так далее, но их материи не касаются.

Когезия - это действие или свойство взаимного притяжения одинаковых молекул. Это внутреннее свойство вещества, обусловленное формой или структурой его молекул, вызывающее изменение в распределении электронов молекул при их сближении, создавая электрическое притяжение, способное образовывать микроскопические структуры, например капли воды.

Адгезия - это сцепление поверхностей разнородных твёрдых и жидких тел.

Если мы не дотрагиваемся атомами до атомов других объектов, почему ощущаем то, к чему «прикасаемся»?

Наш мозг обрабатывает это взаимодействие как реальное прикосновение, потому что нервные окончания пальцев реагируют на то, что поблизости появились другие электроны. Нервные окончания тоже состоят из атомов, и они чувствуют, что на них началось давление, и передают эту информацию мозгу.

Само расстояние между нами и предметом, при соприкосновении, существенно только для микромира. Грубо говоря, в нашем мире оно равно нулю.

А что происходит с пищей, которую мы поглощаем?

Ранее я упоминала о механизме «прикосновения»: мы можем дотронуться до чего-либо, когда наши атомы делятся электронами. Когда пища попадает в 


\section{ВСЕРОССИЙСКИЙ ИССЛЕДОВАТЕЛЬСКИЙ ФОРУМ

организм, еда начинает взаимодействовать с ним. Наше тело забирает все питательные вещества и избавляется от всего, что ему не нужно, то есть образуется химическая реакция.

Явление, когда атомы «собираются» и делятся электронами, случается постоянно. Только в человеческом мозге каждую минуту одновременно идет больше 100 тысяч химических реакций.

Думаю, что каждый слышал фразу: «Мама и папа - наши самые близкие люди». Она тоже касается этой темы. Забегая вперед, хочу сказать, что это чистая правда. Наши родители и дети - единственные люди, которых мы «прикоснулись».

Рождение. Когда мы растем внутри своей матери, ДНК наших родителей химически взаимодействует, чтобы создать нас. Они делятся электронами, то есть атомы соприкасаются. Именно такой процесс можно назвать «прикосновением».

Вирусы.

На нашей планете обитает такая неклеточная форма жизни, которая обладает собственным геномом и способна к воспроизведению лишь в клетках более высокоорганизованных существ- вирус.

Эта микроскопическая частица представляет собой молекулы нуклеиновых кислот (ДНК или РНК), заключенные в белковую оболочку (капсид) и способные инфицировать живые организмы.

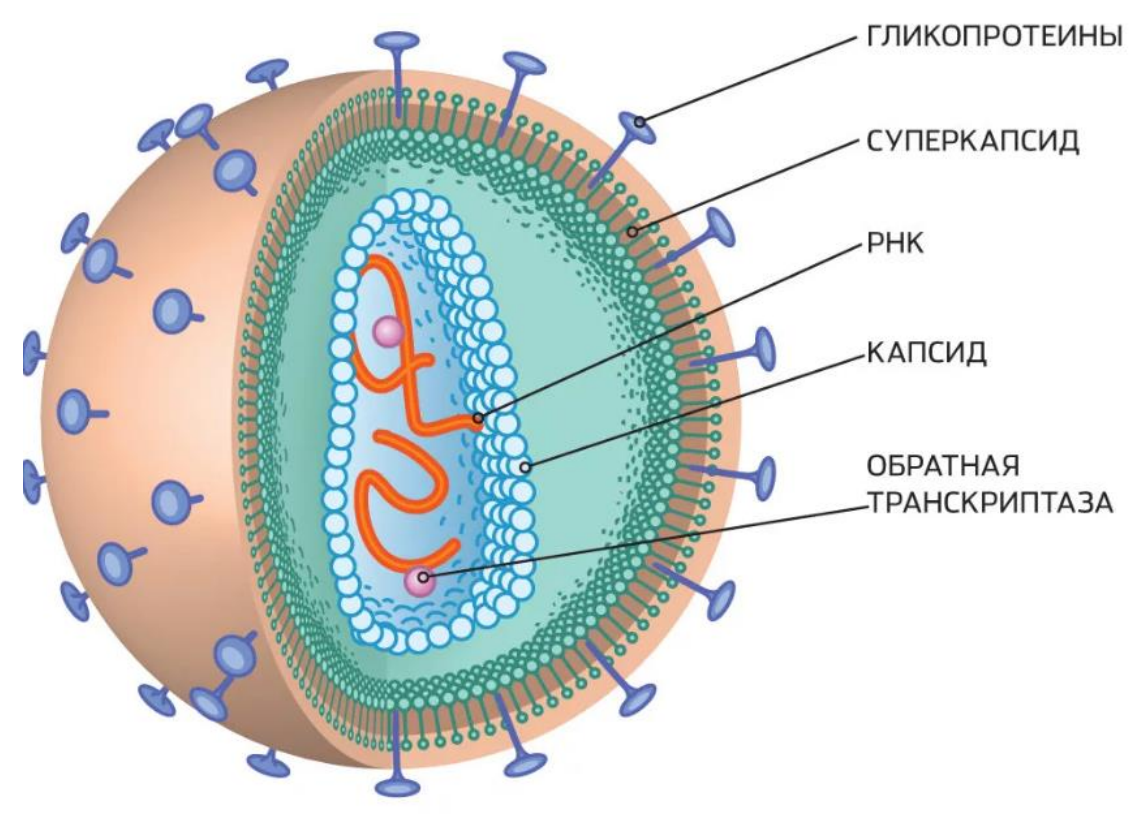

Рис. 2. Строение вируса 


\section{ВСЕРОССИЙСКИЙ ИССЛЕДОВАТЕЛЬСКИЙ ФОРУМ

Для Вирусов в целом характерны две формы жизни: внеклеточная (покоящаяся) и внутриклеточная (размножающаяся) или вегетативная. Они содержат только один тип нуклеиновой кислоты: либо ДНК, либо РНК. Хотя некоторые вирусы имеют сразу оба типа молекул, например: мимивирус.

Процесс инфицирования вирусом. Он разбивается на несколько стадий:

1. Проникновение в клетку.

2. Перепрограммирование клетки.

3. Персистенция.

4. Размножение, созревание и выход из клетки.

Проникновение. Вирус доставляет свою генетическую информацию внутрь клетки, некоторые вирусы переносят собственные белки. То, какую клетку он поразит, определяется рецептором на ее поверхности, поэтому определенный вид вируса может поражать только определенные клетки. Но так как одни и те же рецепторы могут быть на разных видах клеток, то вирус может поражать несколько типов клеток одновременно. Для проникновения в клетку вирусы используют разные пути, например: впрыскивают свою РНК через плазматическую мембрану. Вирусы также различаются по локализации их репликации (процесс создания двух дочерних молекул ДНК), часть вирусов размножается в цитоплазме клетки, а часть - в ее ядре.

Перепрограммирование. Теперь задача вируса- размножиться, используя ресурсы клетки. Но при заражении в клетке активируются специальные механизмы, которые начинают синтезировать сигнальные молекулы - интерфероны, переводящие окружающие здоровые клетки в противовирусное состояние и активирующие системы иммунитета. Существует три основных вида интерферонов:

1. Интерферон-альфа.

2. Интерферон-бета.

3. Интерферон-гамма.

Их общая цель: блокировать работу чужеродных нуклеиновых кислот, не давая вирусу возможности размножаться.

Вирусы, внедрившиеся в клетки, уничтожаются вместе с пораженными клетками Т-киллерами.

Персистенция или переход в неактивное состояние. Некоторые вирусы не вмешиваются в процессы, которые происходят в клетке. Они начитают активироваться только при определенных условиях, но до тех пор находятся в латентном состоянии. 


\section{ВСЕРОССИЙСКИЙ ИССЛЕДОВАТЕЛЬСКИЙ ФОРУМ СТУДЕНТОВ И УЧАЩИХСЯ}

Размножение, созревание и выход из клетки. После синтеза вирусной мРНК, вирусных белков и репликации вирусного генома, одним словомразмножения, новосинтезированные геномные РНК или ДНК, одетые в соответствующие белки, выходят из клетки.

Поражение нашего организма вирусом - достаточно сложный процесс, но благодаря этому знанию мы понимаем, что вирус дотрагивается до нас на атомном уровне, при помощи химических реакций.

\section{Вывод}

После осмысления всего этого, образуется очень интересная гипотеза: в этом мире мы мало к чему можем прикоснуться по-настоящему. Мы не прикасаемся к асфальту, а, грубо говоря, передвигаемся по воздуху. Когда строитель забивает гвоздь, атомы молотка так сильно отталкивают атомы гвоздя, что тот входит в фанеру. После чего уже атомы фанеры давят на атомы гвоздя, не давая ему выйти обратно. И ни в том, ни в другом случае атомы не соприкасаются.

\section{Список литературы}

1. Ахметов Н.С. Общая и неорганическая химия// Электронная оболочка атома-1998- C. 16-27

2. https://smekni.com/a/8210/vidy-fizicheskikh-poley-tela-cheloveka/

(C) Л.М. Сирашева, Э.И. Субханкулова, 2020 